Vol. 1 No. 2, January 2022

e- ISSN 2809 - 1922 , p-ISSN 2809 - 1914

Available online at:

Journal of Applied

Linguistics

https://journal.eltaorganization.org/index.php/joal/index

\title{
AN ANALYSIS OF ILLOCUTIONARY ACTS IN PODCAST RUANG SANDI VIDEOS BY SANDIAGA UNO
}

\author{
Risa Dui Sitorus ${ }^{1}$, Rotua Elfrida $^{2}$. \\ English Literature, University of HKBP Nommensen Medan, Indonesia \\ ${ }^{1}$ risaduisitorus@gmail.com \\ ${ }^{2}$ rotuapangaribuan@uhn.ac.id
}

\begin{abstract}
This study aims to find the types of illocutionary acts and the most dominant types of illocutionary acts of illocutionary used by Sandiaga Uno. The source of data of this study was taken from 4 videos that uploaded in Youtube Channel Podcast Ruang Sandi from MarchApril 2021. And this study only focuses on the illocutionary acts used by Sandiaga Uno. The writer uses a qualitative descriptive method to describe the illocutionary acts by using the theory proposed by Searle in Rahayu (2018:177). After analyzing, the writer found 5 types of illocutionary acts used by Sandiaga Uno in the 4 videos, namely Assertives 33,8\%, Directives $29,5 \%$, Commisives $8,4 \%$, Expressives $21,1 \%$, Declaratives 7,04\%. Based on the percentage, the most dominant used or the most frequently appeared is Assertives 33,8\%. And the types of illocutionary acts assertives used by Sandiaga Uno to informing, describing, and asking to do something and telling the truth about something.
\end{abstract}

Keywords : Pragmatics, Illocutionary Acts, Sandiaga Uno

\section{INTRODUCTION}

Linguistics is a study about language, how the function and how the languages use to put together and make a meaning when people using language to communication with people. Linguistics show the nature of language and where the language come from. Linguistics discuss about the structure of language, the grammar and also forms of language. The branches of linguistics are Pragmatics, Semantics, Morphology, Phonology, Syntax and Sociolinguistics.

Pragmatics is one of the branch of linguistics where people often use. In pragmatics, show what people mean by their utterance that what the words or phrase in those utterance might mean by themselves. Pragmatics have been studied many types such as deixis, presupposition, entailment, politeness, speech act, ect. The illocutionary act is the function of intended meaning in utterance. In simple words, illocutionary acts are the real actions which are performed by the utterance. By studying illocutionary act, people know more knowledge in understanding speaker utterance in certain situation.

Various forms of illocutionary acts can be found in any utterances in videos on social media. such as videos on Facebook, TikTok, Instagram, and YouTube. In this study, the writer is interested in analyzing illocutionary acts in Podcast namely Podcast Ruang Sandi in his Youtube Channel. Podcast Ruang Sandi is considered suitable for the object of illocutionary acts are often 
used by people and most of the speakers do not realize that they perform the illocutionary acts in their utterance. The experience of the writer when watching the videos, movies or dramas there is misunderstand the meaning of the speaker's utterance. The writer wants to know what kind of illocutionary acts Sandiaga Uno used in the video.

\section{Review of Literature}

\section{a. Linguistics}

Linguistics is a study about language, how the function and how the languages use to put together and make a meaning when people using language to communication with people. Linguistics show the nature of language and where the language come from. Linguistics discuss about the structure of language, the grammar and also forms of language. According to Chaer (2012 :3) Linguistics is often referred to as general linguistics, which means that linguistics does not only study a language, but it examines the intricacies of language in general, the language which is a tool for human social interaction. While Aitchison (2000:13) said Linguistics can be defined as "the systematic study of language", a disciplined that describes language in all of it aspects and formulated as to how it functions.From the definitions above, the writer can grasp that linguistics is a scientific study that analyze language from all aspects in order to develop and understand how it works, with the goal of using it as a tool for human social interaction.

\section{b. Pragmatics}

Levinson (1983:5) defines that pragmatics is the study of language use, that is the study of relation between language and context which is basic to an account of language understanding which involves the making of inferences which will connect what is said to what is mutually assumed or what has been said before. Mey (2001 : 5) states that pragmatics is interested in the process of producing language and its producers, not only in the end-product, language. Pragmatics is not only focus on the sentence which uttered by the speaker or written by the /writer. It also pay attention to how, when, where, who are the participants, and why an utterance stated. Based on the explanations above, the writer can understand that pragmatics is the study of contextual meaning which also considers the process of producing utterance.

\section{c. Illocutionary Acts}

Illocutionary act is called by the act of doing something. It is not only used for informing something, but also doing something. Illocutionary act is related to speaker's intention. In other words, every speaker has the intention through their utterance. For utterance, "I promise to meet you at 9am", the utterance is not only a statement, but also binds the speaker to what she/he has just said. Therefore, the illocutionary act of an utterance above is the act of promising.

Every utterance created by people in their communication consists of three related acts that are locutionary, illocutionary, and perlocutionary. Each act has different functions embedded in utterances. Since illocutionary act conveyed the force in delivering the intended meaning of people's utterances, then the writer takes the illocutionary acts as her study objectives.

\section{Types of Figurative Language}

This study uses the speech act theory from Searle. According to Searle in Rahay,FN et al. (2018:177) there are five types of illocutionary act s uch as :

\section{a. Assertives}

The point or purpose of the members of the assertives class is to commit the speaker (in varying degrees) to something being the case, to the truth of the expressed proposition. All of the 
members of the assertive class are assessable on the dimension of assessment which includes true and false. In other word, Assertives are those kinds of illocutionary act that state or express what the speaker believes to be case or not. It shows the truth condition of the meaning of the utterance. The example of this type is stating, suggesting, complaining, claiming, informing, and describing. They express speaker's belief. In performing this type of speech act, the speaker represents the world as she/he believe it is, thus making the world to belief.

Examples :

It was a warm sunny day.

(The speaker describes his/her opinion that the day is warm and sunny as his/her belief although maybe it is a hot sunny day. In this example, the speaker uses the illocutionary acts of assertives, describing)

\section{b. Directives}

The illocutionary point of these consists in the fact that they are attempts (of varying degrees, and hence, more precisely, they are determinates of the determinable which includes attempting) by the speaker to get the hearer to do something. In other word, Directives are illocutionary act that attempts by the speaker to get the hearer to do something. They express about what they want directly to the hearer. It is commonly appear with some performative verbs such as : requesting, demanding, questioning, asking, proposing, advising, suggesting, interrogating, urging, encouraging, inviting, begging, ordering, etc. It's express the speaker's desire or wish for the addressee to do something. In using directives, the speaker intends to elicit some future course of action on the part of the addressee, thus making the world match the world via the addressee.

Examples :

Clean the whiteboard, Melda!

(The speaker wants the hearer (Melda) to do something (to clean the whiteboard). The speaker uses the word "clean" indicating the illocutionary acts of directive, commanding)

\section{c. Commissives}

Commisives are those illocutionary acts whose point is to commit the speaker (again in varying degrees) to some future course of action. The speaker uses word to commit the future action such as promising, offering, threatening, refusing, vowing, and volunteering. It expresses what speaker intends. In using commisives, the speaker undertakes to make the world fit the word (via the speaker).

Examples :

I am able to try my best.

(This brings consequences for the speaker to fulfill what he hassaid. So, the speaker uses the illocutionary act of commissive, vowing)

\section{d. Expressives}

Expressives are those kinds of illocutionary act that express a physhological attitude and state what the speaker feels like joy, sorrow, and like/dislikes, such as thanking, congratulating, pardoning, blaming, praising, condoling. They can be caused by something the speaker or the hearer does, but they are about the speaker's experience.

Examples :

You are so awesome.

(The speaker uses an illocutionary act of expressives praising because from the word "beautiful" the speaker want to express his feeling to the addressee). 


\section{e. Declaratives}

Declaratives are those kinds of illocutionary acts that can change world by the utterance which is produced. The word change which is intended here refers to any situation and changing of the status of a person, or the ownership of something such as resigning, dismissing, christening, naming, excommunicating, appointing, sentencing.

Examples :

I now pronounce you husband and wife.

(The speaker change the condition in reality to ending adressees's single status to get married. The speaker uses the illocutionary act of declaratives declaring)

\section{Podcast Ruang Sandi}

Podcast is defined as audio or video material that is already available on the internet, and can be transferred to our existing devices such as computers, laptops and cellphones. Users of podcasts have a variety of choice (Fadilah, 2017). Podcasts are generally available on two platforms: Spotify and YouTube. In terms of presentation, the two points of view are different. The podcast that are presented through Spotify are only in audio format, whereas the podcasts that are presented through Youtube are in both audio and visual format. In this study, the writer chooses Youtube as a platform for podcast namely Podcast Ruang Sandi that uploaded in Sandiaga Uno's Youtube Channel.

\section{Sandiaga Uno}

Sandiaga Uno was born 28 June 1979 in Rumbai, Pekanbaru, Riau, with the full name Sandiaga Salahuddin Uno. Since 2020, Sandiaga Uno has served as the Republic of Indonesia's Minister of Tourism and Creative Economy. Sandiaga Uno has extensive political and business experience. As a result, Sandiaga Uno launched Podcast Ruang Sandi that can be trusted to share knowledge or tips on how to start a company through invited guests

\section{Research Method}

This study used descriptive qualitative research. Bogdan and Taylor (cited in Basrowi and Suwandi, 20018: 1) say that qualitative research is one of the research procedures that analyze descriptive data in the form of speech or writing and the behaviour of the people observed. Based on the expert opinon above, the writer will use descriptive qualitative method because this method can be used to describe the illocutionary acts that contained in Podcast Ruang Sandi videos on Sandiaga Uno's Youtube Channel .

The writer has taken the data using the following procedures :

a. Downloaded the video podcast.

b. Transcribed the script of the data.

c. Underlined Sandiaga Uno's utterances of illocutionary acts on the video podcast.

The writer has analyzed the data using the following steps:

a. Classified the data related to illocutionary acts such as Assertives, Directives, Commisives, Expressives, Declaratives.

b. Draw conclusion based on the data analysis.

\section{Research Findings}

After analyzing the data, the writer found the types of illocutionary act utterances by Sandiaga Uno as the speaker in Podcast Ruang Sandi Youtube Channel. Here are the number and 
percentage of each types. There are 5 types of illocutionary acts found in Podcast Ruang Sandi. They are : Assertives is 24 i.e 33,8\%, Directives is 21 i.e $29,5 \%$, Commissives is 6 i.e 8,4\%, Expressives is 15 i.e $21,1 \%$, Declaratives is 5 i.e $7.04 \%$.

The dominant types of illocutionary utterances by Sandiaga Uno as the speaker in Podcast Ruang Sandi is Assertives 24 i.e 33,8\% . Assertives is a dominant type because in this podcast Sandiaga Uno mostly expressed his utterances by informing, describing and asking to do something and telling the truth about something.

\section{Conclusion}

Finally, the writer can draw the conclusion and give the suggestion that hopefully will be useful for readers. After analyzing the types of illocutionary acts in Podcast Ruang Sandi videos, the writer would like to conclude that the types of illocutionary acts in Podcast Ruang Sandi are Assertives, Directives, Commisives, Expressives, and Declaratives. The most dominant type is Assertives with a total of $24(33,8 \%)$.

\section{References}

Austin, J. L. 1962. How to Do Things with Words. London : Oxford Uiversity Press.

Aitchison, Jean. 2000. The Articulate Mammal : An Introduction to Psycholinguistics. London and New York: Routledge

Bogdan, Robert C, and Biklen Kopp Sari. 1982. Qualitative Research For Education : An Introduction to Theory and Methods. Allyin and Bacon, Inc. : Boston London

Chaer, Abdul. 2012 . Linguistik Umum. Yogyakarta : Rineka Cipta

Dila Ramayanti, e. a. 2018. The Analysis Of Types Illocutionary Acts In "Tangled Movie". University Negeri Padang.

Fadilah, E. P. 2017. Podcast Sebagai Alternatif Distribusi Konten Audio. . Jurnal Unpad, 90-104.

Harmer, Jeremy. 2007. The Practice Of English Language Teaching (3rd Ed). New York : Longman Publishing

Herman.2015. Illocutionary Acts Analysis Of Chinese In Pematang Siantar . University Of HKBP Nommensen, Medan - Pematang Siantar, Indonesia.

Kreidler, Charles W. 1998. Introducing English Semantics. London and New York : Georgetown University

Leech, G. 1983. Principle Of Pragmatics. New York: Longman.

Levinson, S. C. (n.d.). Pragmatic. Lecturer In Linguistic. University Of Cambridge.

Mey, J. L. 2001. Pragmatics: An Introduction. USA: Blackwell Publisihing.

Murnir, M. 2015. The Analysis of Illocutionary Act In "American Sniper" Movie. Jombang : STKIP Jombang . 
Rahayu, F. A. 2018. Illocutionary Act In The Main Character's Utterances In Mirror Mirror Movie . Indonesia : Mulawarman, University.

Searle, J. R. (n.d.). Expression and Meaning . Studies In The Theory of Speech Acts.

Sholihin, M. N. 2015. An Analysis of Illocutionary Acts Performed by Nemo in "Finding Nemo" , a Movie by Andrew Stanton. Indonesia: State Islamic University Sunan Ampel Surabaya.

Sudaryanto. 1993. Metode dan Aneka Teknik Analisis Bahasa. Yogyakarta: Duta Wacana University Press.

Wardana, Sumita Roy, Juan Ariska. 2019 . Illocutionary Acts In President Rodrigo Duterte's Speech. University of Harapan Medan : Indonesia

Wray, A. a. 2006. Project In Linguistics. London: Hodder Education.

W.H.Inmon 2005 . Building The Data Warehouse. Canada : John Wiley Dan Sons

Yule, G. 1996. Pragmatics. Oxford: Oxford University.

https://voffice.co.id/jakarta-virtual-office/business-tips/biografi-sandiaga-uno-pengusaha-mudakaya-di-indonesia/ 